\title{
Nonlinear regression analysis of length growth in cultured rainbow trout
}

[Análise não linear do crescimento em comprimento de truta-arco-íris de aquicultura]

P.C. Janampa-Sarmiento ${ }^{1}$, R. Takata ${ }^{2}$, T.M. Freitas ${ }^{2}$, M.M.B. Pereira ${ }^{2}$, L. Sá-Freire ${ }^{2}$, V. Lugert $^{4,5}$, C. Sarturi ${ }^{1}$, M.M. Pereira ${ }^{1,3}$

\author{
${ }^{1}$ Aluno de pós-graduação - Instituto de Zootecnia - Universidade Federal Rural do Rio de Janeiro - Seropédica, RJ \\ ${ }^{2}$ Fundação Instituto da Pesca do Estado do Rio de Janeiro - Escritório Regional Serrana - Nova Friburgo, RJ \\ ${ }^{3}$ Fundação Instituto da Pesca do Estado do Rio de Janeiro - Centro de Treinamento \\ de Aquicultura - Rio das Flores, RJ \\ ${ }^{4}$ Alfred Wegener Institute - Helmholtz Centre for Polar and Marine Research - Bremerhaven, Germany \\ ${ }^{5}$ Thünen Institute of Fisheries Ecology - Herwigstraße - Bremerhaven, Germany
}

\begin{abstract}
Length growth as a function of time has a non-linear relationship, so nonlinear equations are recommended to represent this kind of curve. We used six nonlinear models to calculate the length gain of rainbow trout (Oncorhynchus mykiss) during the final grow-out phase of 98 days under three different feed types in triplicate groups. We fitted the von Bertalanffy, Gompertz, Logistic, Brody, Power Function, and Exponential equations to individual length-at-age data of 900 fish. Equations were fitted to the data based on the least square method using the Marquardt iterative algorithm. Accuracy of the fitted models was evaluated using a model performance metrics combining mean squared residuals (MSR), mean absolute error (MAE) and Akaike's Information Criterion corrected for small sample sizes (AICc). All models converged in all cases tested. Evaluation criteria for the Logistic model indicated the best overall fit $(0.67$ of combined metric MSR, MAE and AICc) under all different feeding types, followed by the Exponential model (0.185), and the von Bertalanffy and Brody model (0.074, respectively). Additionally, $\triangle \mathrm{AICc}$ results identify the Logistic and Gompertz models as being substantially supported by the data in $100 \%$ of cases. The logistic model can be suggested for length growth prediction in aquaculture of rainbow trout.
\end{abstract}

Keywords: aquaculture, logistic model, Oncorhynchus mykiss, non-linear equations

\section{RESUMO}

O crescimento em comprimento em função do tempo tem uma relação não linear; por isso, funções não lineares são recomendáveis para descrever essa relação. Seis modelos não lineares foram usados para calcular o ganho em comprimento de truta-arco-íris (Oncorhynchus mykiss) durante 98 dias, na fase final da engorda, submetidas a três dietas diferentes em grupos triplicados. Foram ajustadas as equações de von Bertalanffy, Gompertz, logístico, Brody, função potencial e exponencial a dados individuais de comprimento-idade de 900 peixes. O ajuste foi feito pelo método dos mínimos quadrados, usando-se o algoritmo iterativo de Marquardt. A precisão do ajuste foi avaliada pelo uso de critérios combinados de ajuste: quadrado médio do resíduo (QMR), erro médio absoluto (EMA) e o critério de informação de Akaike corrigido para tamanhos amostrais pequenos (AICc). Todos os modelos atingiram a convergência para cada caso avaliado. Os critérios de avaliação do modelo logístico indicaram o melhor ajuste geral (0,67 vez dos critérios combinados MSR, MAE e AICc) para cada grupo de peixe avaliado, seguido pelo modelo exponencial $(0,185)$ e os modelos von Bertalanffy e Brody, com 0,074, respectivamente. Similarmente, os resultados de $\triangle A I C$ c identificaram-se ao modelo logístico e ao de Gompertz, com grande suporte das informações em $100 \%$ dos casos. Por fim, o modelo logístico pode ser sugerido na predição do crescimento em comprimento de truta-arco-íris cultivada.

Palavras-chave: aquicultura, modelo logístico, Oncorhynchus mykiss, equações não lineares

Recebido em 13 de novembro de 2019

Aceito em 11 de fevereiro de 2020

E-mail: peterjs_0126@hotmail.com 


\section{INTRODUCTION}

Mathematical modeling is defined as the use of equations to describe or simulate processes in a system, such as animal growth (Santos, 2008). Mostly, growth is described as an increase in body dimension (mass, volume or length) as a function of time, and when this relationship is plotted, it results in a growth curve.

Length increase in fish has been studied for a long time in population and fisheries research. In contrast, aquaculture studies mostly refer to body weight. Because both measurement (weight and length) are understood to be largely caused by the same genes (Gunnes and Gjedrem, 1981) weight and length are closely linked by mathematical relationships. Accordingly, length, just as weight, can be affected by the environmental factors present in aquaculture facilities, i.e. tank design (Ross et al., 1995; Üstündağ and Rad, 2014) water quality and stocking density (Person et al., 2008).

Therefore, length growth and other size related treatment studies in cultured fish have received increasing attention since they can be used in the management of aquaculture production (Furuya et al., 2014; Silva et al., 2015; Lugert et al., 2017). In fact, during the last decade the interest to record these growth measurements in situ has grown, in order to improve the automatization of rearing practices in commercial fish aquaculture with the goal to advance in terms of productivity and profitability (Miranda et al., 2017; Saberioon and Císař, 2018).

Predicting growth in aquaculture facilities with high accuracy is possible using statistically based models, i.e. nonlinear equations, since statistical processing software are capable of handling complex mathematical algorithms in order to achieve analytical solutions (Lugert et al., 2016; Powel et al., 2019). Thus, the aim of this work was to fit six nonlinear models to length growth data of cultured rainbow trout by nonlinear regression and evaluate which model or models have the highest accuracy to display the growth curve.

\section{MATERIAL AND METHODS}

The data were collected at a commercial rainbow trout farm. The farm is located in the municipality of Nova Friburgo, a mountain region of the state of Rio de Janeiro, Brazil (22 ${ }^{\circ} 23 ' 36$ "S, $42{ }^{\circ}$ 29'12" W, $1.032 \mathrm{~m}$ altitude). This research was approved by the Ethics Committee on Animal Use (CEUA) of the Rio de Janeiro State Fisheries Foundation-FIPERJ with document number 007/2017007/2017.

The fish, without sex distinction, were acquired from the farms' own breeding program. Nine hundred fish with an age of 273 days post-hatch (dph), and length (fork length) mean of $22.42 \pm$ $0.71 \mathrm{~cm}$, were selected. Fish were distributed randomly into nine masonry tanks with a volume of $40 \mathrm{~m}^{3}$ each. Fish were fed with three different types of extruded pellets (two commercials diets, $\mathrm{A}$ and $\mathrm{B}$, and one experimental diet, $\mathrm{C}$ ) in triplicates $[(\mathrm{A} / 1, \mathrm{~A} / 2, \mathrm{~A} / 3)(\mathrm{B} / 1, \mathrm{~B} / 2, \mathrm{~B} / 3)(\mathrm{C} / 1$, $\mathrm{C} / 2, \mathrm{C} / 3)]$. Rations were offered twice a day until apparent saturation. The experimental period was 98 days. Length measures at the beginning and the end of the trial for each feed type are shown in Table 1 .

The six nonlinear equations chosen were von Bertalanffy, Brody, Gompertz, Logistic, Exponential, and Power Function; the mathematical expression of each function is presented in Table 2. Models were fitted using the Levenverg-Marquardt algorithm through the nlsLM computational process in the statistical software R (Elzhov et al., 2015). This process uses the nonlinear least squares (nls) method. The default convergence conditions were used with the exception of the maximum number of iterations being increased to 1000 . 
Table 1. Average length (AL) of cultured rainbow trout in centimeters with Standard Deviation (SD) at the beginning and the end of grow-out phase

\begin{tabular}{|c|c|}
\hline Diet/Repetition & $\mathrm{AL}(\mathrm{cm}) \pm \mathrm{SD}$ \\
\hline Beginning & \\
\hline All repetitions & $22,42 \pm 0,71 \mathrm{~cm}$ \\
\hline Final & \\
\hline $\mathrm{A} / 1$ & $32.31 \pm 1.62$ \\
\hline $\mathrm{A} / 2$ & $29.80 \pm 1.88$ \\
\hline $\mathrm{A} / 3$ & $32.06 \pm 1.45$ \\
\hline $\mathrm{B} / 1$ & $33.09 \pm 1.41$ \\
\hline$B / 2$ & $33.00 \pm 1.66$ \\
\hline $\mathrm{B} / 3$ & $33.42 \pm 1.69$ \\
\hline $\mathrm{C} / 1$ & $33.07 \pm 1.78$ \\
\hline $\mathrm{C} / 2$ & $33.45 \pm 1.72$ \\
\hline $\mathrm{C} / 3$ & $33.01 \pm 1.84$ \\
\hline
\end{tabular}

Table 2. Mathematical expression of the seven equations fitted to length growth data of cultured rainbow trout

\begin{tabular}{|c|c|c|}
\hline Models & Equation & References \\
\hline Bertalanffy & $Y=A *\left(1-\exp \left(-B *\left(t-T_{0}\right)\right)\right.$ & Bertalanffy, 1934 \\
\hline Brody & $Y=A *(1-C * \exp (-B * t))$ & Brody, 1945 \\
\hline Logistic & $Y=A *(1+\exp (-B *(t-T)))^{-1}$ & Pearl, 1930 \\
\hline Gompertz & $Y=A * \exp (-\exp (-B *(t-T)))$ & Tjorve and TJorve, 2017 \\
\hline Exponential & $Y=L_{0} * \exp (t * k)$ & Santos et al., 2008 \\
\hline Power Function & $Y=L_{0} *\left(t^{\mathrm{k}}\right)$ & Huxley, 1932 \\
\hline
\end{tabular}

The accuracy of the fitted models was evaluated using a model performance metrics. The performance criteria to evaluate the goodness of fit are: The mean squared residuals $(M S R=$ $\left.R S S *[n-p]^{-1}\right)$; where $\mathrm{RSS}$ is the residual sum of squares, $\mathrm{n}$ is the number of observations, $\mathrm{p}$ is the number of parameters of the model (Rawlings et al., 1998). The Akaike Information Criterion (AIC) corrected for small sample sizes (AICc). $A I C=2 k-2 \ln (\hat{L})$; where $k$ is the number of estimated parameters in the model and $\hat{L}$ is the maximum value of the likelihood function for the model, and $l n$ is the natural logarithm (Akaike, 1973). AIC $c=\mathrm{AIC}+\frac{2 \mathrm{k}^{2}+2 k}{\mathrm{n}-\mathrm{k}-1}$; where $n$ is the sample size and $k$ is the number of parameters.

We calculated the difference in AICc $(\triangle \mathrm{AICc})$ values to test the support of inferior models by the data. $\triangle \mathrm{AICc}$ is calculated as: $\mathrm{AICc}\left(\mathrm{AICc}_{\mathrm{i}}-\mathrm{AICc}\right.$ min) (Katsanevakis and Maravelias, 2008). Models with $\triangle \mathrm{AICc}>10$ have no support from the data, while models with $\triangle \mathrm{AICc}<2$ have substantial support (Burnham and Anderson, 2002). Models with $\triangle \mathrm{AICc}$ between 4-7 are somewhat supported by the data and might be taken into consideration.
The Mean Absolute Error (MAE) is the average absolute difference between observed and predicted outcomes and is calculated as: $M A E=$ mean $(\mid$ observed - predicted $\mid)$. The MSR, AICc, and MAE were calculated using SAS (Statistical..., 2013). Finally, the results from MSR, AICc, and MAE were analyzed using a scoring system in which each best fit accounted for one score. The model that had the best fit in most tested cases achieved the highest score. In addition, we interpreted the estimated regression parameters of each model in regard to the biological attributes of the species whenever possible.

\section{RESULTS}

All models met convergence in all (9 of 9 evaluations) tested cases through LevenvergMarquardt's iterative method. All models needed a comparably low number of iterations, and convergence was generally met within 100 iterations. The estimated parameters for each model are shown in Table 3 . 
Nonlinear regression...

Table 3. Estimated parameters of Bertalanffy, Brody, Logistic, Gompertz, Exponential and Power function

\begin{tabular}{|c|c|c|c|c|c|c|}
\hline Diet/Repetition & Bertalanffy & Brody & Logistic & Gompertz & Exponential & Power Function \\
\hline $\mathrm{A} / 1$ & & & & & --- & --- \\
\hline$A$ & 680.637 & 350.691 & 353.047 & 10740.9 & --- & --- \\
\hline$B$ & 0.0001 & 0.0003 & 0.0040 & 0.0006 & --- & --- \\
\hline$T_{0}$ & 59.533 & --- & --- & --- & --- & --- \\
\hline$T$ & --- & --- & 930.653 & 3156.32 & --- & --- \\
\hline$C$ & --- & 1.0205 & --- & --- & --- & --- \\
\hline$L_{0}$ & --- & --- & --- & --- & 7.9986 & 0.02517 \\
\hline$K$ & --- & --- & --- & --- & 0.0038 & 1.2097 \\
\hline \multicolumn{7}{|l|}{$\mathrm{A} / 2$} \\
\hline$A$ & 630.258 & 422.841 & 925.313 & 30423 & --- & --- \\
\hline$B$ & 0.0001 & 0.0002 & 0.0030 & 0.0004 & --- & --- \\
\hline$T_{0}$ & -14.539 & --- & --- & --- & --- & --- \\
\hline$T$ & --- & & 1491.86 & 5010.23 & --- & --- \\
\hline$C$ & --- & 0.9979 & --- & --- & --- & --- \\
\hline$L_{0}$ & --- & --- & --- & --- & 9.8555 & 0.1116 \\
\hline$K$ & --- & --- & --- & --- & 0.0029 & 0.9421 \\
\hline \multicolumn{7}{|l|}{$\mathrm{A} / 3$} \\
\hline$A$ & 127.134 & 127.133 & 48.1825 & 59.0688 & --- & --- \\
\hline$B$ & 0.001 & 0.001 & 0.0086 & 0.0048 & --- & --- \\
\hline$T_{0}$ & 81.7453 & --- & --- & --- & --- & --- \\
\hline$T$ & --- & --- & 290.004 & 267.306 & --- & --- \\
\hline$C$ & --- & 1.086 & --- & --- & --- & --- \\
\hline$L_{0}$ & --- & --- & --- & --- & 8.1859 & 0.0279 \\
\hline$K$ & --- & --- & --- & --- & 0.0037 & 1.1919 \\
\hline \multicolumn{7}{|l|}{$\mathrm{B} / 1$} \\
\hline$A$ & 47.6917 & 47.6918 & 39.627 & 42.2835 & --- & --- \\
\hline$B$ & 0.0058 & 0.0058 & 0.0144 & 0.0101 & --- & --- \\
\hline$T_{0}$ & 164.443 & --- & --- & & --- & --- \\
\hline$T$ & --- & --- & 255.23 & 228.48 & --- & --- \\
\hline$C$ & --- & 2.6016 & --- & --- & --- & --- \\
\hline$L_{0}$ & --- & --- & --- & --- & 7.633 & 0.0159 \\
\hline$K$ & --- & --- & --- & --- & 0.004 & 1.2946 \\
\hline \multicolumn{7}{|l|}{$B / 2$} \\
\hline$A$ & 88.5135 & 88.5139 & 46.3962 & 54.5543 & --- & --- \\
\hline$B$ & 0.0018 & 0.0018 & 0.0101 & 0.0059 & --- & --- \\
\hline$T_{0}$ & 113.95 & --- & --- & --- & --- & --- \\
\hline$T$ & --- & --- & 280.435 & 254.149 & --- & --- \\
\hline$C$ & --- & 1.23147 & --- & --- & --- & --- \\
\hline$L_{0}$ & --- & --- & --- & --- & 7.59 & 0.0165 \\
\hline$K$ & --- & --- & --- & --- & 0.004 & 1.2868 \\
\hline \multicolumn{7}{|l|}{$B / 3$} \\
\hline A & 60.645 & 60.6451 & 43.0691 & 47.8483 & --- & --- \\
\hline B & 0.0036 & 0.0036 & 0.0124 & 0.0079 & --- & --- \\
\hline T0 & 145.668 & --- & --- & --- & --- & --- \\
\hline $\mathrm{T}$ & --- & & 266.573 & 238.481 & --- & --- \\
\hline $\mathrm{C}$ & --- & 1.694 & --- & --- & --- & --- \\
\hline L0 & --- & --- & --- & --- & 7.3661 & 0.0127 \\
\hline $\mathrm{K}$ & --- & --- & --- & --- & 0.0041 & 1.3341 \\
\hline
\end{tabular}

Parameter $A$, values range between 39.63 and 10740.9. Within each group, the lowest value was mostly obtained by the Logistic and Gompertz models, while the highest value was usually estimated by the Bertalanffy and Brody models. In contrast, values in parameter $B$ range between 0.00144 and 0.0001 with the lowest values being obtained by the Brody and Bertalanffy models, and the highest values by the Logistic and Gompertz models. Parameter $T$ ranges between 5010.23 and 228.48 in the Gompertz model, and between 1491.86 and 255.23 in the Logistic model. Parameter $T_{0}$ for the von Bertalanffy model has values between -14.539 to 164.443 . 
Table 3 (continue). Estimated parameters of Bertalanffy, Brody, Logistic, Gompertz, Exponential, and Power Function models

\begin{tabular}{|c|c|c|c|c|c|c|}
\hline Diet/Repetition & Bertalanffy & Brody & Logistic & Gompertz & Exponential & Power Function \\
\hline \multicolumn{7}{|l|}{$\mathrm{C} / 1$} \\
\hline$A$ & 75.084 & 75.084 & 45.5924 & 52.3174 & --- & --- \\
\hline$B$ & 0.0023 & 0.0023 & 0.0103 & 0.0063 & --- & --- \\
\hline$T_{0}$ & 119.958 & --- & --- & --- & --- & --- \\
\hline$T$ & --- & --- & 275.762 & 246.341 & --- & --- \\
\hline$C$ & --- & 1.3212 & -- & -- & --- & --- \\
\hline$L_{0}$ & --- & --- & --- & --- & 7.7727 & 0.0186 \\
\hline$K$ & --- & --- & --- & --- & 0.0039 & 1.2663 \\
\hline \multicolumn{7}{|l|}{$\mathrm{C} / 2$} \\
\hline$A$ & 309.924 & 244.385 & 52.7605 & 68.3329 & --- & --- \\
\hline$B$ & 0.0004 & 0.0005 & 0.0088 & 0.0046 & --- & --- \\
\hline$T_{0}$ & 89.1451 & --- & --- & --- & --- & --- \\
\hline$T$ & --- & --- & 308.098 & 297.346 & --- & --- \\
\hline$C$ & --- & 1.05 & --- & --- & --- & --- \\
\hline$L_{0}$ & --- & --- & --- & --- & 7.3111 & 0.0131 \\
\hline$K$ & --- & --- & --- & --- & 0.0041 & 1.3263 \\
\hline \multicolumn{7}{|l|}{$\mathrm{C} / 3$} \\
\hline$A$ & 80.0456 & 80.0459 & 45.4537 & 52.7584 & --- & --- \\
\hline$B$ & 0.0021 & 0.0021 & 0.0105 & 0.0063 & --- & --- \\
\hline$T_{0}$ & 120.185 & --- & --- & --- & --- & --- \\
\hline$T$ & --- & --- & 276.587 & 249.388 & --- & --- \\
\hline$C$ & --- & 1.2927 & --- & --- & --- & --- \\
\hline$L_{0}$ & --- & --- & --- & --- & 7.5515 & 0.0159 \\
\hline$K$ & --- & --- & --- & --- & 0.004 & 1.2929 \\
\hline
\end{tabular}

$L_{0}$ values are between 7.31 and 9.85 for the Exponential model, and between 0.0127 and 0.0279 for the Power Function Model. Similarly, $k$ values are between 0.0029 and 0.0041 for the Exponential model, and between 1.3341 and 1.3341 for the Power Function Model. $k$ values are between 0.004 to 0.041 for the Exponential model, and between 0.9421 to 1.3341 for the Power Function model. Graphic growth simulations for dph (days post hatch) 100 to 600 by each equation are shown in Figure 1 for threeparameter functions (Logistic, von Bertalanffy, Gompertz and Brody models) and, two-parameter functions (Power Function and Exponential models).

The model performance metrics for each model are presented in Table 4. Lowest MSR-values are produced by the Logistic model in 0.67 of tested cases, followed by the Von Bertalanffy $(0.11)$, Brody (0.11), Exponential (0.11) and Power Function (0.11) models. The Gompertz model did not perform the lowest MSR in any case. MAE is lowest in the Logistic model in 5 out of 9 tested groups, 0.55 respectively. The Gompertz, Exponential and Power function models produced lowest MAE once (0.11) (Table 4).
The AICc values of each model and all tested cases are listed in Table 4. Lowest AICc values are most often obtained by the Logistic model (6 of 9 cases). The Exponential model produced lowest AICc in 2 out of 9 cases, and the von Bertalanffy and Brody model both achieved lowest AICc values in 1 of 9 cases. The Gompertz and Power Function models never achieve lowest AICc.

The overall score obtained by the models are presented at the bottom of Table 4. Undisputedly, the Logistic model achieved the best overallscoring with 18 of 27 best fits (0.67). The Exponential model achieved best overall fit in 5 of 27 cases. The von Bertalanffy, and the Brody models scored only 2 out of 27 (0.07), and the Gompertz, and Power Function models achieved best fit just in one tested case and criteria (0.04). $\triangle \mathrm{AICc}$ values range between 0.026 as the lowest and 44.61 as the highest. The Logistic and Gompertz models had substantial support by the data in all cases (Table 4). The von Bertalanffy and Brody models in 6 cases and, the Exponential and Power Function models in 2 cases each. 

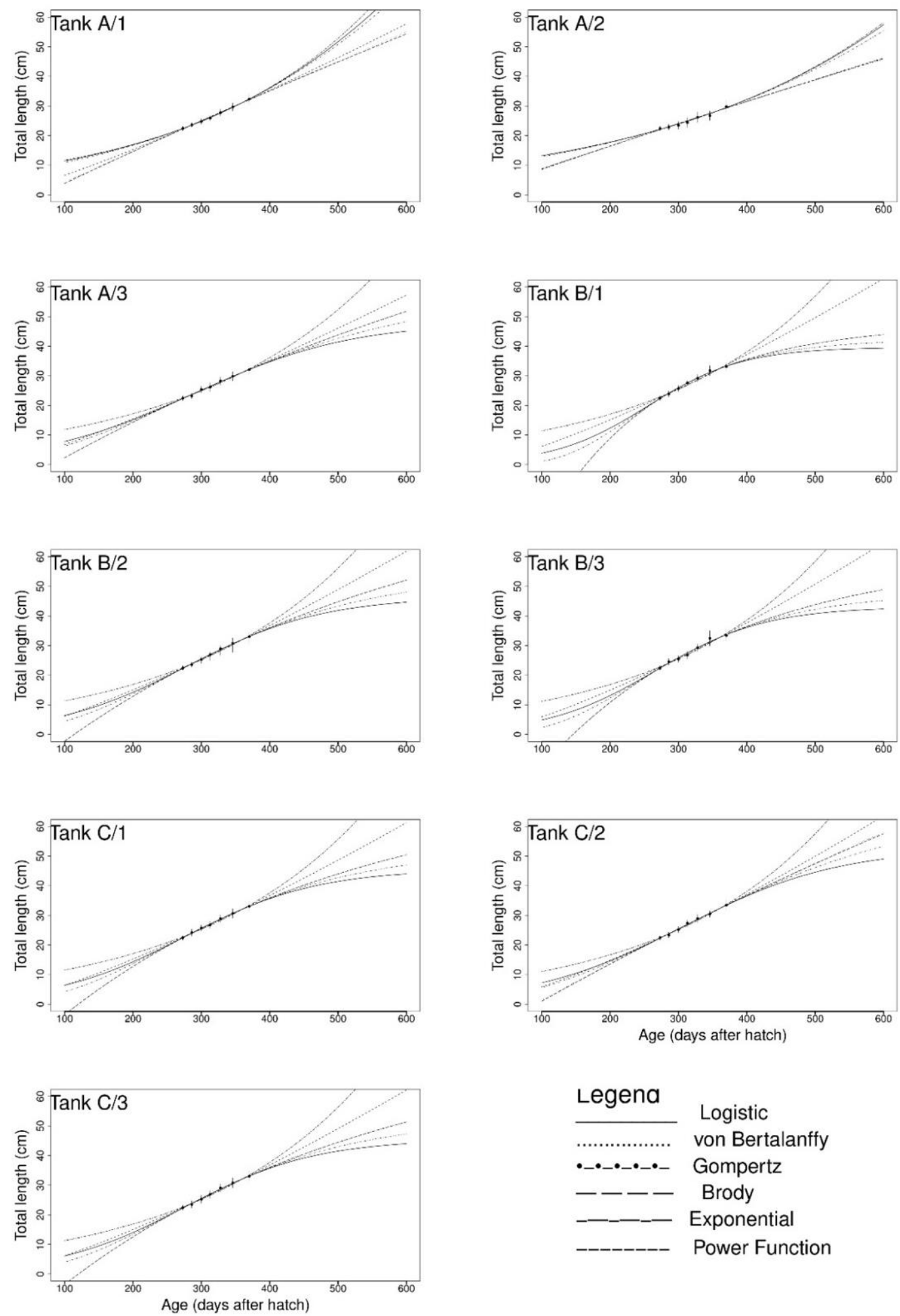

Figure 1. Growth simulations of rainbow trout from 100 until 600 age-days obtained by Logistic (solid line), von Bertalanffy (dotted), Gompertz (dot dash), Brody (long dash), Exponential (two dash) and Power function (dashed) models. Average length in $\mathrm{cm}(\circ) \pm$ Standard Deviation. 
Table 4. Goodness of fit criteria of the von Bertalanffy, Brody, Logistic, Gompterz, Exponential and Power Function equations fitted to length gain data of rainbow trout. Mean Square Residual (MSR), Mean Absolute Error (MAE) and Akaike Information Criterion corrected for small sample sizes (AICc). $\triangle \mathrm{AICc}$ values indicate support of the model by the data. *best value on same criteria. **number of times that the best score for each model is met

\begin{tabular}{|c|c|c|c|c|c|c|}
\hline $\begin{array}{c}\text { Diet } \\
\text { Criteria }\end{array}$ & Bertalanffy & Brody & Logistic & Gompertz & Exponential & $\begin{array}{c}\text { Power } \\
\text { Function }\end{array}$ \\
\hline \multicolumn{7}{|l|}{$\mathrm{A} / 1$} \\
\hline MSR & 1.2147166 & 1.217811 & 1.1796001 & 1.1801987 & $1.1737527 *$ & 1.194842 \\
\hline MAE & 0.8236849 & 0.824574 & 0.8183127 & $0.8180777^{*}$ & 0.8188233 & 0.820356 \\
\hline $\mathrm{AICc}$ & 598.4779364 & 598.979191 & 592.6988709 & 592.7988288 & $592.6727535^{*}$ & 596.180959 \\
\hline $\begin{array}{l}\Delta \mathrm{AICc} \\
\mathrm{A} / 2\end{array}$ & 5,805 & 6,306 & 0,026 & 0,126 & 0,000 & 3,508 \\
\hline MSR & 2.12683 & 2.128863 & 2.046860 & 2.055098 & $2.034366 *$ & 2.117822 \\
\hline MAE & 1.11847 & 1.119290 & 1.094625 & 1.097862 & $1.093890 *$ & 1.118859 \\
\hline $\mathrm{AICc}$ & 701.63786 & 701.824204 & 694.164381 & 694.947650 & $693.922849 *$ & 701.762634 \\
\hline$\triangle \mathrm{AICc}$ & 7,715 & 7,901 & 0,242 & 1,025 & 0,000 & 7,840 \\
\hline \multicolumn{7}{|l|}{$\mathrm{A} / 3$} \\
\hline MSR & 1.4333163 & 1.4333163 & $1.4308570 *$ & 1.432026 & 1.4826628 & 1.4324416 \\
\hline MAE & 0.9358926 & 0.9358926 & $0.9349358 *$ & 0.935386 & 0.9506103 & 0.9365388 \\
\hline $\mathrm{AICc}$ & 631.0775059 & 631.0775059 & $630.7392007^{*}$ & 630.900026 & 638.6985844 & 631.9101009 \\
\hline$\triangle \mathrm{AICc}$ & 0,338 & 0,338 & 0,000 & 0,161 & 7,959 & 1,171 \\
\hline \multicolumn{7}{|l|}{$\mathrm{B} / 1$} \\
\hline MSR & 1.2999818 & 1.2999818 & $1.2862617^{*}$ & 1.2928879 & 1.6090242 & 1.4409779 \\
\hline MAE & 0.9030997 & 0.9030996 & $0.8998888^{*}$ & 0.9015261 & 0.9885733 & 0.9384269 \\
\hline $\mathrm{AICc}$ & 605.6428412 & 605.6428412 & $603.5738641^{*}$ & 604.5758229 & 648.1843622 & 626.6747177 \\
\hline$\triangle \mathrm{AICc}$ & 2,069 & 2,069 & 0,000 & 1,002 & 44,610 & 23,101 \\
\hline \multicolumn{7}{|l|}{$\mathrm{B} / 2$} \\
\hline MSR & 1.3745884 & 1.3745884 & $1.3689902 *$ & 1.3716829 & 1.4727694 & 1.3902388 \\
\hline MAE & 0.8820453 & 0.8820452 & $0.8791945^{*}$ & 0.8804776 & 0.9140912 & 0.8842226 \\
\hline $\mathrm{AICc}$ & 619.6801683 & 619.6801683 & $618.8803047^{*}$ & 619.2654429 & 634.1548813 & 622.8517529 \\
\hline$\triangle \mathrm{AICc}$ & 0,800 & 0,800 & 0,000 & 0,385 & 15,275 & 3,971 \\
\hline \multicolumn{7}{|l|}{$\mathrm{B} / 3$} \\
\hline MSR & 2.144757 & 2.144757 & $2.127780 *$ & 2.136353 & 2.350096 & 2.210897 \\
\hline MAE & 1.022760 & 1.022760 & $1.021003 *$ & 1.021942 & 1.084951 & 1.038324 \\
\hline $\mathrm{AICc}$ & 703.274695 & 703.274695 & $701.724975^{*}$ & 702.509058 & 722.055856 & 710.149607 \\
\hline$\triangle \mathrm{AICc}$ & 1,550 & 1,550 & 0,000 & 0,784 & 20,331 & 8,425 \\
\hline \multicolumn{7}{|l|}{$\mathrm{C} / 1$} \\
\hline MSR & $1.5411509 *$ & $1.5411509 *$ & 1.5423322 & 1.5416740 & 1.6465393 & 1.5620830 \\
\hline MAE & 0.9567037 & 0.9567037 & $0.9565924^{*}$ & 0.9566168 & 0.9970732 & 0.9699101 \\
\hline $\mathrm{AICc}$ & $642.0976960 *$ & $642.0976960 *$ & 642.2478726 & 642.1642159 & 656.0149855 & 645.6945052 \\
\hline$\triangle \mathrm{AICc}$ & 0,000 & 0,000 & 0,150 & 0,067 & 13,917 & 3,597 \\
\hline \multicolumn{7}{|l|}{$\mathrm{C} / 2$} \\
\hline MSR & 1.3967752 & 1.3968260 & $1.3949278^{*}$ & 1.3957112 & 1.4559129 & 1.395989 \\
\hline MAE & 0.9172188 & 0.9175387 & 0.9158973 & 0.9165441 & 0.9292423 & $0.915059 *$ \\
\hline $\mathrm{AICc}$ & 622.8184881 & 622.8256100 & $622.5590881^{*}$ & 622.6691286 & 631.8986434 & 623.660770 \\
\hline$\triangle \mathrm{AICc}$ & 0,259 & 0,267 & 0,000 & 0,110 & 9,340 & 1,102 \\
\hline \multicolumn{7}{|l|}{$\mathrm{C} / 3$} \\
\hline MSR & 1.807639 & 1.807639 & $1.799842 *$ & 1.803624 & 1.918966 & 1.827667 \\
\hline MAE & 1.012463 & 1.012463 & $1.009982 *$ & 1.011283 & 1.032893 & 1.013757 \\
\hline $\mathrm{AICc}$ & 676.787560 & 676.787560 & $675.935976^{*}$ & 676.349501 & 689.514099 & 679.911158 \\
\hline$\triangle \mathrm{AICc}$ & 0,852 & 0,852 & 0,000 & 0,414 & 13,578 & 3,975 \\
\hline Score*** & 2 & 2 & 18 & 1 & 5 & 1 \\
\hline
\end{tabular}

\section{DISCUSSION}

Convergence is met when the iterative process successfully estimates parameters for the function within the given maximum number of iterations set in the fitting algorithm. In this study, all models met convergence in all tested cases using the Marquardt algorithm. This algorithm is described to be more robust than others offered on statistical software (Elzhov, et al., 2015; Lugert et $a l ., 2017)$. This is especially important, as nonconvergence situations of models for aquaculture data are described by several authors (Costa et al., 2009; Mansano et al., 2012; Allaman et al., 2013; Sousa et al., 2014). 
Parameter $A$ for three-parameter models (von Bertalanffy, Brody, Logistic and Gompertz) describe the infinite size of an organism and can be interpreted as the possibility of the model to reflect the biological properties of the species. $O$. mykiss is known to exceed $120 \mathrm{~cm}$ in length (Eaton et al., 1995). Accordingly, Logistic and Gompertz models, estimated $A$ within the biological range of the species in 7 of 9 cases, and for von Bertalanffy and Brody models in 5 of 9 cases.

Parameter $B$ for three-parameter models denotes the precocity index. This means the larger the numeric value, the quicker the fish will reach the asymptotic or infinite size (Malhado et al., 2009). Estimated $B$ values for Logistic and Gompertz models $(0.0001$ and 0.0144$)$ in this study have the tendency to be greater than those being obtained from wild rainbow trout $(0.002$ to 0.049$)$ in 7 and 6 of 9 cases, respectively (Blair et al., 2013; Sloat and Reeves, 2014; Cilbiz and Yalim, 2017). Similarly, Lugert et al. (2016) found similar differences in parameter $B$ between cultured and wild Scophthalmus maximus, referring these differences to the positive effect of controlled environmental conditions in recirculating aquaculture systems (RAS). There are no differences in parameter $B$ observed between von Bertalanffy and Brody models, having values between 0.001 and 0.058 . The Logistic model had the highest values of $B$ followed by the Gompertz model. Von Bertalanffy and Brody models generally have the lowest values. Contrary to our findings, Gomiero et al. (2009) showed larger $B$ estimates for Brody and von Bertalanffy models on length growth of cultured Brycon orbignyanus. Our results agree with results by Santos et al. (2013) on length growth modeling of Oreochromis niloticus.

The point of inflection (POI) (parameter T) of the growth curve is only parameterized in the Gompertz and the Logistic model. At the POI, the rate of grow this largest, before diminishing asymptotically against zero. In this study, $T$ values obtained by the Gompertz and Logistic models are generally lower than those estimated by Sloat and Reeves (2014) in weight data of wild rainbow trout using the Gompertz model. Furthermore, in aquaculture operations, the parameter $T$ can be useful in the empiric adjustment of management strategies, as it is proven to correlate with other husbandry information. For instance, $T$ parameter has significant meaning on cultured Carassius auratus gibelio because it positively correlates with dietary protein levels (Yun et al., 2015). Likewise, Oreochromis niloticus shows significant influence of water temperature on weight gain and at the age at the inflexion point (Santos et al., 2013).

Parameter $T_{0}$ for the von Bertalanffy model defines the hatching day of rainbow trout. In this study, this parameter does not have congruence with biological features since it is not possible to have negative or positive hatching age (up to 54 days). Similarly, parameter $\mathrm{L}_{0}$ for Exponential and Power Function models which define the hatching length differ between both models. In addition, $L_{0}$ of the Power function model shows values $(0.0127$ to $0.1116 \mathrm{~cm})$ smaller than the biologic features of rainbow trout (1.2 to $2 \mathrm{~cm}$ ) as described by Lavens and Sorgeloos (1996).

Parameter $k$ represents the constant growth rate of rainbow trout trough all growth-curve for Exponential and Power Function model. $k$ values of Exponential model are lower than those obtained by the Power Function. These values must be taken with care since both models display exponential shape and are not intended for longer growth periods or extrapolation of data. However, because of their simplicity they are frequently used in aquaculture studies (Santos et al., 2008; Costa et al., 2009).

In model selection, the goodness of fit should generally not be based on a single criterion. Correspondingly, it has become common practice to evaluate the most suitable model based on an evaluation metrics of mostly three statistical parameters of different properties (e.g. Yun et al., 2015; Lugert et al., 2017; Powell et al., 2019). One parameter should be based on the residuals from fitting the model. The second parameter is often based on information theory either AIC, AICc or BIC. A third parameter is mostly somehow based on the deviation between estimated and sampled data. For these three categories of evaluation parameters, several different statistical parameters are available. In each scenario, the author needs to decide individually, which parameter is most suitable for the current study.

In our study, we used Mean Squared Residual (MSR), Akaike Information Criterion for small sample sizes (AICc) and Mean Absolute Error 
(MAE). The non-linear least squares method aims to achieve non-linear equation parameter by minimizing the Residual Sum of Squares (RSS). The smaller RSS, the smaller the MSR and the better the fit (Rawlings et al., 1998). In this study, the Logistic model most often achieved the smallest MSR values. Similar results were obtained by Costa et al. (2009) in growth studies of Orechormis niloticus, but are in contrast to Mansano et al. (2012) on Lithobates catesbeianus, with both species being reared under aquaculture conditions.

We used $\triangle \mathrm{AICc}$ to identify whether our datasets were supported by more than one model. This was necessary, as the outcome from the analysis revealed very close numeric results between different models within tested groups. $\triangle \mathrm{AICc}<2$ indicates substantial support of a model by the data (Burnham and Anderson, 2002). Indeed, in all 9 analysis, 2 out of 6 tested models were supported by the data, namely Logistic and Gompertz. This might be due to the specific pattern of our recorded data (grow-out phase), which are distributed around the POI of the growth curve. Accordingly, several models of sigmoidal behavior can equally well reflect this segment of the curve.

Primarily, we observed that the different nonlinear models adjusted their fit individually to the various growth trajectories expressed by rainbow trout caused by different diet treatments. Araneda et al. (2013) observed similar results when fitting models on various growth data of Penaeus vannamei. This specific application has huge potential in predicting the effects of new feed formulations, harvest size and production period in all aquaculture species. However, it is necessary to verify and validate this potential through studies with rigorous control of diet quality and quantity as recorded in carp (Yun et al., 2015).

\section{CONCLUSION}

All six models (von Bertalanffy, Brody, Logistic, Gompertz, Exponential and Power Function) have shown the capacity to fit the length-at-age data of cultured rainbow trout during the grow-out phase. However, in the current study, the Logistic model achieved the highest accuracy in fit. Despite the growth-length curve of cultured rainbow trout not clearly follows a sigmoidal shape, the diminishing-return shaped von Bertalanffy and Brody models, as well as the exponential shaped Power Function and Exponential models do not meet the mathematical attributes needed to reflect length-at-age data. This is also verified by $\triangle \mathrm{AICc}$ values, which indicate the Logistic and Gompertz model, as the only models having substantial support by the data in all cases. Furthermore, we showed that it is possible to model the impact of varies feeding strategies to predict long-term influences on growth and harvest size and production period.

\section{ACKNOWLEDGMENTS}

This study was financed by the Co-ordination of Higher-Level Population Survey - Brazil (CAPES) - Finance Code 001, The National Council for Scientific and Technological Development (CNPq) Process number 141889/2019-5, Araribá Trout Farm, and by C.N. Rações. The authors want to thank Victor Octavio Borda Pua for his help with the suggestion of codes on the R software.

\section{COMMITTEE ON ETHICS AND BIOSAFETY}

The procedures adopted were approved by the Ethics Committee on Animal Use (CEUA) of the Rio de Janeiro State Fisheries FoundationFIPERJ, document number 007/2017, been in accordance with the ethical principles in animal experimentation elaborated by the Brazilian College of Animal Experimentation (COBEA).

\section{REFERENCES}

AKAIKE, H. Information theory and an extension of the maximum likelihood principle. In: PETROV, B.N.; CSÁKI, F.(Eds.). Information theory. Budapest: Akadémiai Kiadó, 1973. p.267281.

ALLAMAN I.; REIS NETO, R.V.; FREITAS, R.T.F. et al. Weight and morphometric growth of different strains of tilapia (Oreochromis $s p$ ). Rev. Bras. Zootec., v.42, p.305-311, 2013.

ARANEDA, M.E.; et al. Growth modelling including size heterogeneity: Application to the intensive culture of white shrimp ( $P$. vannamei) in freshwater. Aquac. Eng., V.56, p.1-12. 2013. 
BERTALANFFY, L.V. Untersuchungen uber die gesetzlichkeit des wachstums. I. Allgemeine grundlagen der theorie: mathematische und physiologische gesetzlichkeiten des wachstums bei wassertieren. Wilhelm Roux Arch. Entwicklungsmech. Org., v.131, p.613-653, 1934.

BLAIR, J.M.; OSTROVSKY, L.S.; HICKS, B.J. et al. Growth of rainbow trout (Oncorhynchus mykiss) in warm-temperate lakes: implications for environmental change. Can. J. Fish. Aquatic Sci., v.70, p.815-823, 2013.

BRODY, S. Bioenergetics and growth. New York: Rheinhold Publishing, 1945. 1023p.

BURNHAM, K.P.; ANDERSON, D.R. Model Selection and Inference. New York: Springer, 1998. 515p.

CILBIZ, M.; YALIM, F.B. Growth, mortality, recruitment and yield of rainbow trout, Oncorhynchus mykiss (Walbaum, 1792) in Karacaören-I Dam Lake, Turkey. Pak. J. Zool., v.49, p.825-832, 2017.

COSTA, A.C.; REIS NETO, R.V.; FREITAS, R.T.F. et al. Avaliação do crescimento de tilápias de diferentes linhagens através de modelos não lineares. Arch. Zootec., v.58, p.561-564, 2009.

EATON, J.G.; MCCORMICK, J.H.; GOODNO, B.E. et al. A field information-based system for estimating fish temperature tolerances. Fisheries, v.20, p.10-18, 1995.

ELZHOV, T.V.; MULLEN, K.M.; SPIESS, A.M. et al. Package 'minpack. lm'.CRAN repository. 2015.

FURUYA, V.R.B.; MICHELATO, M.; CRUZ, T.P.; FURUYA, W.M. Length-weight relationships and prediction equations of body composition of farm raised Astyanax aff. Fasciatus (Actinopterygii: characiformes: Characidae). Zoologia, v.6, p.521-524, 2014.

GOMIERO, J.S.G.; FREITAS, R.T.F.; SANTOS, V.B. et al. Curvas de crescimento morfométrico de piracanjuba (Brycon orbignyanus). Ciênc. Agrotecnol., v.33, p.882-889, 2009

GUNNES, K.; GJEDREM, T. A genetic analysis of body weight and length in rainbow Trout reared in seawater for 18 months. Aquaculture, v.24, p.161-174, 1981.

HUXLEY, J.S. Problems of relative growth. London: Methuen \& Co, 1932. [308p.].
KATSANEVAKIS, S.; MARAVELIAS, C.D. Modelling fish growth: multi-model inference as a better alternative to a priori using von Bertalanffy equation. Fish Fish., v.9, p.178-187, 2008.

LAVENS, P.; SORGELOOS, P. Manual on the production and use of life food for aquaculture. Ghent: FAO Fish Tech Pap, 1996. n.361, p.1-2.

LUGERT, V. A review on fish growth calculation: multiple functions in fish production and their specific application. Rev. Aquacul., v.8, p.30-42, 2016.

LUGERT, V.; TETENS, J. THALLER, G. et al. Finding suitable growth models for turbot in aquaculture 1 (length application). Aquacul. Res., v.48, p.24-36, 2017.

MALHADO, C.H.M.; CARNEIRO, P.L.S.; AFFONSO, P.R.A.M. et al. Growth curves in Dorper sheep crossed with the local Brazilian breeds, Morada Nova, Rabo Largo, and Santa Inês. Small Ruminant Res. v.84, p.16-21, 2009.

MANSANO, C. STÉFANI, M.V.; PEREIRA, M.M.; MACENTE, B.I. Non-linear growth models for bullfrog tadpoles. Ciênc. Agrotecnol., v.36, p.454-462, 2012.

MIRANDA, J.M.; ROMERO, M. A prototype to measure rainbow trout's length using image processing. Aquacul. Eng., V.76, p.41-49, 2017.

PEARL RAYMOND. Introduction to medical biometry and statistics. Saunders, Second Edition. 459p. 1930.

PERSON J. LABBÉ, L.; BAYON, N.; SÉVÈRE, A. Combined effects of water quality and stocking density on welfare and growth of rainbow trout (Oncorhynchus mykiss). Aquatic Living Res., v.21, p.185-195, 2008.

POWELL C.; LÓPEZ, S.; FRANCE, J. Elementary functions modified for seasonal effects to describe growth in freshwater fish. $J$. Theor. Biol., v.461, p.133-144, 2019.

RAWLINGS J.O.; PANTULA, J.O.; DICKEY, D.A. Applied regression analysis. 2.ed. New York: Springer-Verlag, 1998. 659p.

ROSS R.M.; WATTEN, B.J.; KRISE, W.F. et al. Influence of tank design and hydraulic loading on the behavior, growth, and metabolism of rainbow trout (Oncorhynchus mykiss). Aquacul. Eng., v.14, p.29-47, 1995. 
SABERIOON, M.; CÍSǍ̌, P. Automated within tank fish mass estimation using infrared reflection system. Comp. Elect. Agricul., v.150, p.484-492, 2018.

SANTOS, V.B.; MARECO, E.A.; SILVA, M.P. Growth curves of Nile tilapia (Oreochromis niloticus) strains cultivated at different temperatures. Acta Sci. Anim. Sci., v.35, p.235242, 2013.

SANTOS, V.B.; RILKE, E.Y.; FREITAS, T.F. et al. Exponential growth model of Nile tilapia (Oreochromis niloticus) strains considering heteroscedastic variance. Aquaculture, v.274, p.96-100, 2008.

SILVA, T.S.; SANTOS, L.D.; SILVA, L.C. et al. Length-weight relationship and prediction equations of body composition for growingfinishing cage-farmed Nile tilapia. Rev. Bras. Zootec., v.44, p.133-137, 2015.

SLOAT, M.R.; REEVES, G.H. Individual condition, standard metabolic rate, and rearing temperature influence steelhead and rainbow trout (Oncorhynchus mykiss) life histories. Can. J. Fish. Aquatic Sci., v.71, p.491-501, 2014.
SOUSA, J.; GARRIDO, M.S.; CARVALHO, P.G.S. et al. Mathematical modeling applied to the growth of tilapia in net cages in the sub middle of the São Francisco River. Eng. Agríc., v.34, p.1001-1011. 2014.

STATISTICAL analysis system. Version 9.4. Cary: SAS Institute, 2013

TJøRVE, K.M.C.; TJØRVE, E. The use of Gompertz models in growth analyses, and new Gompertz-model approach: An addition to the Unified-Richards family. PLoS One v.12: p.e0178691, 2017.

ÜSTÜNDAĞ, M.; RAD, F. Effect of different tank colors on growth performance of rainbow trout juvenile (Oncorhynchus mykiss Walbaum, 1792). J. Agricul. Sci.; v.21, p.144-151, 2015.

YUN, B.; YU, X.; XUE, M. et al. Effects of dietary protein levels on the long-term growth response and fitting growth models of gibel carp (Carassius auratus gibelio). J. Anim. Nutr., v.1, p.70-76, 2015. 